\title{
Deterioration of goat spermatozoa in skimmed milk-based extenders as a result of oleic acid released by the bulbourethral lipase BUSgp60
}

\author{
M-T. Pellicer-Rubio and Y. Combarnous \\ Station de Physiologie de la Reproduction des Mammifères Domestiques, Institut National de la Recherche \\ Agronomique (INRA), Centre National de la Recherche Scientifique (CNRS) Unit 1291, \\ 37380 Nouzilly, France
}

\begin{abstract}
The aim of the present study was to elucidate the mode of action of goat bulbourethral lipase (BUSgp60 lipase) previously identified as responsible for the deterioration of goat sperm viability in skimmed milk-based extenders. Milk fractions were purified by micro- and ultrafiltration and characterized by SDS-PAGE, thin layer chromatography, triglyceride quantitative analysis and by their ability to potentiate the lipase and the sperm-deteriorating activity of the bulbourethral lipase. Components in both the phosphocaseinate and soluble whey protein fractions enhanced the lipase activity of BUSgp60 but only the phosphocaseinate fraction, which contains triglycerides, promoted deterioration of spermatozoa in the presence of bulbourethral gland secretion. These data suggest that the sperm-deteriorating effect of bulbourethral gland secretion is due to the catalysis of triglyceride hydrolysis, and that proteins increase this activity. BUSgp 60 hydrolysed milk triglycerides and triolein very effectively, and its lipase activity was enhanced by several highly purified milk proteins. The major cis-unsaturated fatty acid from milk (oleic acid) but not the major saturated fatty acid (palmitic acid) exhibited dose-dependent detrimental effects on goat spermatozoa. Therefore, the catalysis of oleic acid formation from residual milk triglycerides by BUSgp60 appears responsible for the deterioration of goat spermatozoa when unwashed semen is diluted in skimmed milk-based extenders. The precise mechanism of action of oleic acid remains to be elucidated but the drawbacks of washing buck semen might be avoided by inhibiting BUSgp60 or by depriving it of substrate.
\end{abstract}

\section{Introduction}

Skimmed milk is used in the extenders for goat (Capra hircus) semen because of its protective role during semen cooling and freezing. However, seminal plasma has an adverse effect on the survival of goat spermatozoa stored frozen in milk-based extenders (Corteel, 1974, 1975, 1980; Memom et al, 1985). Thus, the storage of goat semen in the presence of milk requires that most of the seminal plasma is removed before dilution of spermatozoa. Seminal plasma is removed by dilution of ejaculated spermatozoa in an isotonic buffer followed by centrifugation (washing method). Washing improves the survival of spermatozoa after freezing and thawing (Corteel, 1974). Nevertheless, this is a complex and time-consuming method that results in loss and damage to spermatozoa (Pickett et al., 1975; Padilla and Foote, 1991; Alvarez et al., 1993; Graham, 1994).

Mature goat spermatozoa from the cauda epididymis, which have not been in contact with the accessory gland secretions, have been used to evaluate the effects of individual secretions from goat accessory sexual glands on sperm viability. Bulbourethral gland secretion (BUS) has been found to be the

Received 8 April 1997. component of goat seminal plasma responsible for the deterioration of the motility and acrosome integrity of epididymal spermatozoa diluted in skimmed milk during incubation at $37^{\circ} \mathrm{C}$ (Corteel, 1980; Nunes, 1982; Nunes et al., 1982; Courtens et al., 1984). A $40-60 \mathrm{kDa}$ protein from BUS has been shown to be responsible for this effect (Nunes, 1982; Corteel, 1990) and, more recently, this bulbourethral component has been identified as a $55-60 \mathrm{kDa}$ glycoprotein lipase (BUSgp60 lipase) related to pancreatic lipase-related protein 2 (PLRP2) (Pellicer-Rubio et al., 1997).

Deterioration of motility and of acrosome integrity of goat epididymal spermatozoa promoted by BUS at $37^{\circ} \mathrm{C}$ is observed when milk is present but not when an isotonic saline buffer is used as a sperm diluent (Nunes, 1982; Courtens et al., 1984; Corteel, 1990). However, the role of milk in the deterioration of spermatozoa by BUS lipase is unknown. Nunes (1982) and Corteel (1990) suggest that an enzyme from BUS acts on a milk substrate to give a toxic product. Recently, a $55-60 \mathrm{kDa}$ glycoprotein lipase from goat BUS (BUSgp60) was purified and characterized (Pellicer-Rubio et al. 1997). BUSgp60 is structurally related to pancreatic lipase-related protein 2 (PLRP2) and, thus, could also display phospholipase activity (Hjorth et al., 1993; Carrière et al., 1994; Thirstrup et al., 1994). The sperm-deteriorating effect of BUSgp 60 may be either direct 
through the hydrolysis of membrane phospholipids of spermatozoa or indirect through the production of toxic derivative(s) from milk lipids.

The present study demonstrates that the deteriorating effect of BUS on spermatozoa is indirect since it is only observed with milk protein fractions containing residual triglycerides or with highly purified proteins to which triglycerides have been added. Moreover, oleic acid derived from triolein hydrolysis by BUS lipase also adversely affected goat spermatozoa.

\section{Materials and Methods}

\section{Enzymes and lipids}

Lipase (EC 3.1.1.3) type VI-S from pig pancreas (34000 U $\mathrm{mg}^{-1}$ of protein) and pure triolein (1,2,3-[cis-9-octadecenoyl] glycerol), palmitic (Hexadecanoic acid) and oleic acid (cis-9octadecenoic acid) were purchased from Sigma (Saint-QuentinFallavier).

\section{Recovery of bulbourethral secretion and purification of BUSgp60}

Bulbourethral glands from Alpine and Saânen male goats were recovered during the breeding season at a local abattoir and their secretion (BUS) was collected by gentle pressure. BUS proteins were then solubilized with $0.1 \%(\mathrm{w} / \mathrm{v})$ sodium deoxicolate in Tris buffer (10 mmol Tris- $\mathrm{HCl} \mathrm{l}^{-1}, \mathrm{pH} 7.4$ and $150 \mathrm{mmol} \mathrm{NaCl} \mathrm{l}{ }^{-1}$ ) at room temperature under agitation for $3 \mathrm{~h}$. The samples were then centrifuged at $10000 \mathrm{~g}$ for $30 \mathrm{~min}$ (Pellicer-Rubio et al., 1997) and the supernatants were equilibrated with $100 \mathrm{mmol}$ ammonium bicarbonate $\mathrm{l}^{-1}$ buffer either by dialysis or gel filtration. Finally, they were lyophilized and stored at $4^{\circ} \mathrm{C}$ until use.

Purification of the BUS component responsible for the sperm deterioration in skimmed milk (BUSgp60 lipase) was carried out by HPLC (HPLC 650 Waters, Milford, MA) at $1 \mathrm{ml} \mathrm{min}^{-1}$ with Tris buffer (10 mmol Tris-HCl $1^{-1}, \mathrm{pH} \mathrm{7.4)}$ onto a SP15HR column (Waters). A solution of $10 \mathrm{mg}$ BUS in $5 \mathrm{ml}$ Tris buffer was loaded and BUSgp 60 was eluted with a $45 \mathrm{~min}$ linear gradient from 0 to $0.4 \mathrm{~mol} \mathrm{NaCl} \mathrm{l}{ }^{-1}$ (Pellicer-Rubio et al., 1997). Immediately after purification, BUSgp60 was stored at $-20^{\circ} \mathrm{C}$ at an approximate concentration of $0.15 \mathrm{mg} \mathrm{ml}^{-1}$.

\section{Preparation of milk fractions}

Four milk fractions were purified at the INRA Milk Technology Laboratory (Rennes) by physical procedures (micro- and ultrafiltration) to preserve the physicochemical properties of milk components. Briefly, skimmed cow milk was microfiltered at $50^{\circ} \mathrm{C}$ through an aluminum-zirconum membrane (pore diameter: $0.1 \mu \mathrm{m}$ ) to give a retentate containing milk colloidal components and a microfiltrate (MF) containing the milk soluble components at a concentration similar to that in milk. The MF was then ultrafiltered through a membrane with a cut-off limit of $3 \mathrm{kDa}$ to separate soluble whey proteins (SWP) from the ultrafiltrate fraction (UF). The native phosphocaseinate fraction (NPC) was prepared from skimmed milk by tangential membrane microfiltration (pore diameter: $0.2 \mu \mathrm{m}$ ) followed by diafiltration with distilled water (Pierre et al., 1992). Skimmed milk and its MF and UF fractions were stored at $-20^{\circ} \mathrm{C}$, the SWP fraction was diafiltrated with distilled water, lyophilized and stored at $4^{\circ} \mathrm{C}$ and the NPC was spray-dried and stored at room temperature. The chemical compositions of skimmed milk and its MF and NPC fractions have been published by Pierre et al. (1992).

Soluble whey proteins (SWP) such as $\beta$-lactoglobulin and $\alpha$-lactalbumin were fractionated by size-exclusion chromatography on an AcA 44 column (Sepracor-IBF, Villeneuve-laGarenne). Chromatography was carried out with $100 \mathrm{mmol}$ ammonium bicarbonate $\mathrm{l}^{-1}$ at $50 \mathrm{ml} \mathrm{h}^{-1}$ at $4^{\circ} \mathrm{C}$. The proteins were detected at $280 \mathrm{~nm}$, lyophilized and stored at $4^{\circ} \mathrm{C}$. Pure $\alpha$ and $\kappa$-caseins were purchased from Sigma. Pure $\beta$-caseins were kindly provided by the INRA Milk Technology Laboratory (Rennes).

Solubilization of NPC in MF (NPC/MF) or in UF (NPC/UF) was carried out at $25 \mathrm{mg} \mathrm{ml}^{-1}$ which is close to its concentration in milk. Therefore, NPC/MF can be regarded as reconstituted skimmed milk, whereas NPC/UF can be regarded as reconstituted skimmed milk lacking whey proteins. Moreover, MF represents casein-free skimmed milk and UF, protein-free skimmed milk.

\section{Characterization of milk fractions}

Protein characterization. The protein composition of each milk fraction was checked by SDS-PAGE (Laemmli, 1970) using a $15 \%$ acrylamide separating gel. The proteins were visualized by Coomassie blue R-250 staining. Pure $\alpha, \beta$ and $\kappa$ caseins, $\beta$-lactoglobulin, $\alpha$-lactalbumin and proteins of the LMW calibration kit (Pharmacia, Uppsala) were used as references.

Lipid characterization. The qualitative composition of milk lipids was analysed by thin layer chromatography. Lipids were extracted at room temperature for $15 \mathrm{~min}$ in $1.5 \mathrm{ml}$ methanolchloroform 2:1 (v/v) mixture. Then, $6 \mu \mathrm{l}$ formic acid, $500 \mu \mathrm{l}$ distilled water and $500 \mu \mathrm{I}$ chloroform were added and the mixtures were vortexed and centrifuged at $2000 \mathrm{~g}$ for $30 \mathrm{~min}$ to recover the lipids in the chloroform layer. The remaining layers were washed successively with $1 \mathrm{ml}$ and $0.5 \mathrm{ml}$ chloroform, and all chloroform fractions were pooled. After drying under $\mathrm{N}_{2}$, they were redissolved with $50 \mu \mathrm{l}$ methanolchloroform $2 / 1(\mathrm{v} / \mathrm{v})$ mixture for subsequent thin layer chromatography analysis on silica gel-60 plate (Merck, Darmstadt). The plates were developed with a 165/35/2 (v/v/v) mixture of petroleum ether, diethyl ether and acetic acid. The spots were visualized by spraying with $50 \% \mathrm{H}_{2} \mathrm{SO}_{4}$ in ethanol and heating in an oven at $150^{\circ} \mathrm{C}$ until charring occurred. Pure triolein and oleic acid were used as references.

A quantitative enzymatic determination of triglycerides in skimmed milk, NPC/UF, MF and UF samples was carried out using the commercially available glycerol kinase start procedure (Sigma) based on the method described by Bucolo and 
Table 1. Effects of goat bulbourethral lipase (BUSgp60 lipase) and pig pancreatic lipase (pPL) on the quality parameters of goat spermatozoa diluted in $10 \%$ dehydrated skimmed milk or KRPG

\begin{tabular}{|c|c|c|c|c|c|}
\hline Diluent & Enzyme & $\begin{array}{c}\text { Motile } \\
\text { spermatozoa } \\
(\%)\end{array}$ & $\begin{array}{l}\text { Quality of } \\
\text { movement }\end{array}$ & $\begin{array}{c}\text { Undamaged } \\
\text { acrosomes } \\
(\%)\end{array}$ & $\begin{array}{l}\text { Live } \\
\text { spermatozoa } \\
(\%)\end{array}$ \\
\hline & $\begin{array}{c}\text { BUSgp60 } \\
\left(\mu \mathrm{g} \mathrm{ml}^{-1}\right)\end{array}$ & & & & \\
\hline \multirow[t]{2}{*}{ 10\% Milk } & 0 & $80.8 \pm 2.3^{\mathrm{a}}$ & $4.3 \pm 0.1^{a}$ & $93.1 \pm 0.7^{\mathrm{a}}$ & $87.0 \pm 1.4^{a}$ \\
\hline & 6 & $2.3 \pm 0.8^{\mathrm{b}}$ & $0.5 \pm 0.1^{\mathrm{b}}$ & $2.3 \pm 0.6^{b}$ & $2.1 \pm 0.9^{b}$ \\
\hline \multirow[t]{3}{*}{ KRPG } & 0 & $58.3 \pm 4.0^{c}$ & $4.5 \pm 0.1^{\mathrm{a}}$ & $93.2 \pm 0.8^{\mathrm{a}}$ & $90.5 \pm 2.0^{a}$ \\
\hline & 6 & $58.3 \pm 3.3^{c}$ & $4.3 \pm 0.1^{\mathrm{a}}$ & $91.6 \pm 1.0^{a}$ & $88.4 \pm 2.1^{a}$ \\
\hline & $\begin{array}{c}\mathrm{pPL} \\
\left(\mathrm{U} \mathrm{ml}^{-1}\right)\end{array}$ & & & & \\
\hline \multirow[t]{2}{*}{$10 \%$ Milk } & 0 & $85.0 \pm 2.5^{\mathrm{a}}$ & $3.8 \pm 0.1^{\mathrm{a}}$ & $93.5 \pm 1.2^{\mathrm{a}}$ & $90.8 \pm 0.9^{a}$ \\
\hline & 400 & $0.5 \pm 0.2^{\mathrm{b}}$ & $0.3 \pm 0.1^{b}$ & $4.2 \pm 0.6^{\mathrm{b}}$ & $0.1 \pm 0.1^{b}$ \\
\hline \multirow[t]{2}{*}{ KRPG } & 0 & $42.5 \pm 3.0^{c}$ & $3.8 \pm 0.1^{\mathrm{a}}$ & $93.0 \pm 1.7^{\mathrm{a}}$ & $84.8 \pm 1.4^{\mathrm{a}}$ \\
\hline & 400 & $41.7 \pm 1.6^{c}$ & $3.6 \pm 0.1^{\mathrm{a}}$ & $93.8 \pm 0.8^{a}$ & $87.3 \pm 1.5^{\mathrm{a}}$ \\
\hline
\end{tabular}

Each value represents the mean \pm SEM of six replicates.

Measurements were performed after 60 min incubation at $37^{\circ} \mathrm{C}$.

abcValues in the same column with different superscripts differ significantly (confidence intervals multiple comparison: $P<0.01$ ).

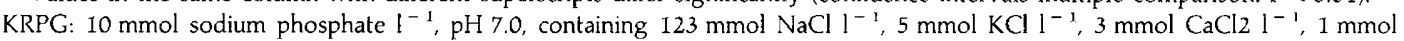
$\mathrm{MgSO}_{4} \mathrm{I}^{-1}$ and $0.2 \% \alpha$-D-glucopyranose.

David (1973). Triglyceride concentration in test samples was referred to a standard dose-response curve of triolein.

\section{Analysis of lipase activity}

Lipase activity determination was carried out using a commercial kit (Sigma) based on the titrimetric method of Tiez and Fiereck (1966). The lipase activity of $5 \mu \mathrm{g}$ BUS was analysed using $3 \mathrm{ml} 50 \%$ olive oil as the substrate in a total volume of $7.5 \mathrm{ml}$ after a $20 \mathrm{~h}$ incubation at $37^{\circ} \mathrm{C}$ at $\mathrm{pH} 8.0$. The lipase activity was expressed as the volume of $50 \mathrm{mmol} \mathrm{NaOH} \mathrm{l}^{-1}$ required to neutralize the fatty acids liberated during incubation (Sigma Units) and was calculated by subtracting the volume of $\mathrm{NaOH}$ used for the blank flask from that used for the test flasks.

\section{Preparation of spermatozoa and analysis of sperm viability}

Testes from Alpine and Saânen male goats were collected at a local abattoir and were brought to the laboratory at room temperature within $1 \mathrm{~h}$. Mature epididymal spermatozoa were expelled from cauda epididymis by retroflushing with paraffin oil. Immediately, the spermatozoa were diluted $1: 9(\mathrm{v} / \mathrm{v})$ at room temperature in an isotonic saline solution KRPG (10 mmol sodium phosphate $\mathrm{I}^{-1}, \mathrm{pH} 7.0$, containing $123 \mathrm{mmol}$ $\mathrm{NaCl} \mathrm{l^{-1 }}, 5 \mathrm{mmol} \mathrm{KCl} \mathrm{l}^{-1}, 3 \mathrm{mmol} \mathrm{CaCl}_{2} \mathrm{l}^{-1}, 1 \mathrm{mmol}$ $\mathrm{MgSO}_{4} 1^{-1}$ and $0.2 \% \alpha$-D-glucopyranose) and, for sperm quality evaluation, these were finally diluted $1: 9(\mathrm{v} / \mathrm{v})$ in KRPG, skimmed milk or in different milk fractions. When $10 \%$ dehydrated skimmed milk was used as final diluent (10 g cow skimmed milk dehydrated and $0.2 \mathrm{~g} \alpha$-D-glucopyranose in $100 \mathrm{ml}$ distilled water), this media was warmed to $92^{\circ} \mathrm{C}$ for $10 \mathrm{~min}$ and allowed to cool before addition of spermatozoa (Corteel, 1974). When used, palmitic acid, oleic acid or triolein were first dissolved in a few microlitres of ethanol and then dispersed in the sperm diluents by vigorous stirring and sonication of the mixture. When required, $0.2 \%(\mathrm{w} / \mathrm{v})$ D-glucose was added and the osmolarities of all diluents were in the range of $280-300 \mathrm{mOs}$.

The percentage of motile spermatozoa, the quality of movement estimated on a scale from 0.0 (all spermatozoa are immotile) to 5.0 (motile spermatozoa exhibit a fast progressive movement), the percentage of spermatozoa with an undamaged acrosome and the percentage of live spermatozoa were estimated. These parameters were analysed after incubating $1 \mathrm{ml}$ samples of spermatozoa in a water bath at $37^{\circ} \mathrm{C}$ for a maximum of $60 \mathrm{~min}$. The sperm motility parameters were assessed under a coverslip on a warm microscope stage at $37^{\circ} \mathrm{C}$ using a phase-contrast microscope. The morphology of the acrosome was examined in sperm samples fixed 1:9 $(\mathrm{v} / \mathrm{v})$ in $2 \%$ $(\mathrm{v} / \mathrm{v})$ glutaraldehyde-PBS-solution, under a phase-contrast microscope at $\times 64$ magnification by counting 200 spermatozoa per sample. For sperm viability assessments, samples of spermatozoa were diluted $(\mathrm{v} / \mathrm{v})$ in eosin-nigrosin stain $(2.5 \%$ eosin and $5 \%$ nigrosin in PBS $\mathrm{pH} 6.7$ buffer) at $37^{\circ} \mathrm{C}$ for a few seconds. Next, sperm samples were placed on slides, airdried and examined under a bright-field microscope at $\times 100$ magnification by counting 200 spermatozoa per sample. Those spermatozoa that had taken up the eosin stain were classified as eosinophilic, or dead cells; the remaining spermatozoa were classified as noneosinophilic or living cells (Chauhan and Anand, 1990). The assessor did not know the identity of the samples.

\section{Statistical analyses}

Each experiment was replicated at least four times. The dose-response data of lipase activities were fitted by nonlinear 


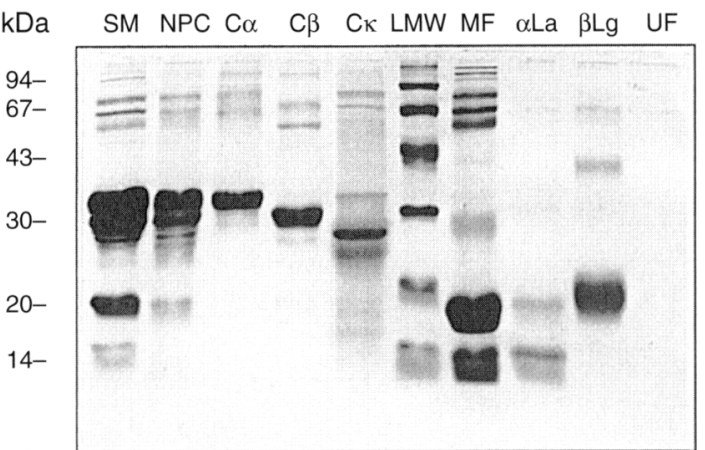

$-\beta \operatorname{Lg}$

$-\alpha \mathrm{La}$

Fig. 1. SDS-PAGE ( $15 \%$ acrylamide, sodium dodecyl sulfate polyacrylamide gel electrophoresis) of reduced samples of $1 \mu$ l skimmed milk (SM), $15 \mu \mathrm{g}$ native phosphocaseinate fraction (NPC), $10 \mu \mathrm{l}$ microfiltrate (MF) and $10 \mu \mathrm{l}$ ultrafiltrate fraction (UF). Pure $\alpha$-casein $(\mathrm{C} \alpha)$ $\beta$-casein $(C \beta)$, $\kappa$-casein $(C \kappa)$, $\alpha$-lactalbumin ( $\alpha \mathrm{L} a)$ and $\beta$-lactoglobulin $(\beta \mathrm{Lg})$ were used as references. LMW: molecular mass markers.

sigmoidal regression and analysed using the Sigma Plot (Jandel) program. The sperm quality parameters were analysed either by multifactor analysis of variance (diluents $\times$ enzyme dose) followed by confidence intervals multiple comparison or by one-way analysis of variance followed by confidence intervals multiple comparison. Differences were considered significant at $P<0.05$.

\section{Results}

\section{Involvement of milk in the BUS-promoted sperm deterioration}

For confirmation that the presence of milk is mandatory for the expression of the sperm-deteriorating activity of BUS, the effects of purified BUSgp60 or pig pancreatic lipase (pPL) on sperm quality parameters were examined after $60 \mathrm{~min}$ incubation at $37^{\circ} \mathrm{C}$ in skimmed milk or KRPG diluents. For each enzyme tested, multifactor analysis of variance (diluent $x$ enzyme dose) revealed differences between diluents or enzyme concentration $(P<0.0001)$. Interaction between both variables $(P<0.0001)$ was also established. When BUSgp60 lipase or pPL were added to skimmed milk diluent, strong and significant decreases $(P<0.01)$ in the percentage of motile spermatozoa, sperm movement quality, percentage of spermatozoa with undamaged acrosome and percentage of live spermatozoa were observed (Table 1). In contrast, no significant effect on these parameters was observed in KRPG diluent $(P>0.05)$. These results demonstrate that one or several milk components are involved in the sperm deterioration promoted by purified BUSgp60 and pPL.

\section{Identification of milk component(s) potentiating the lipase activity} of BUSgp 60

The component(s) responsible for the highly potentiating effect of milk on BUSgp60 lipase activity (Pellicer-Rubio et al., 1997) were identified by checking the homogeneity of each milk fraction by SDS-PAGE (Fig. 1). The fractions were overloaded on the gel to detect eventual minor contaminants.

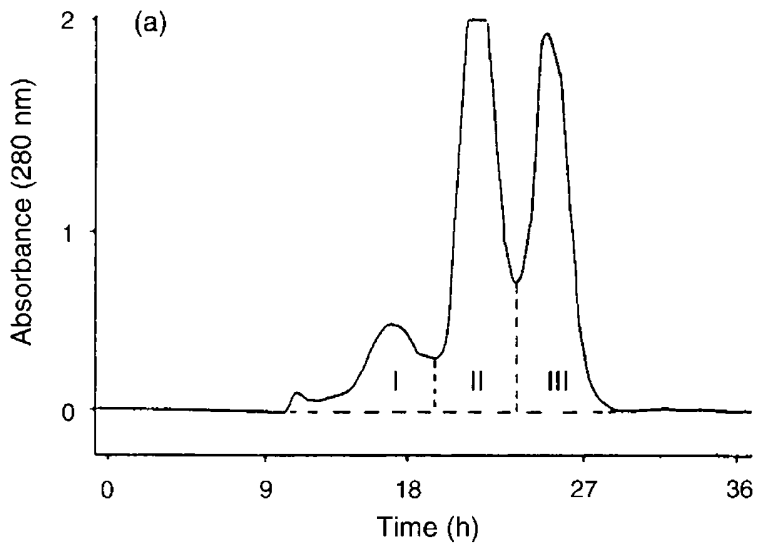

(b)

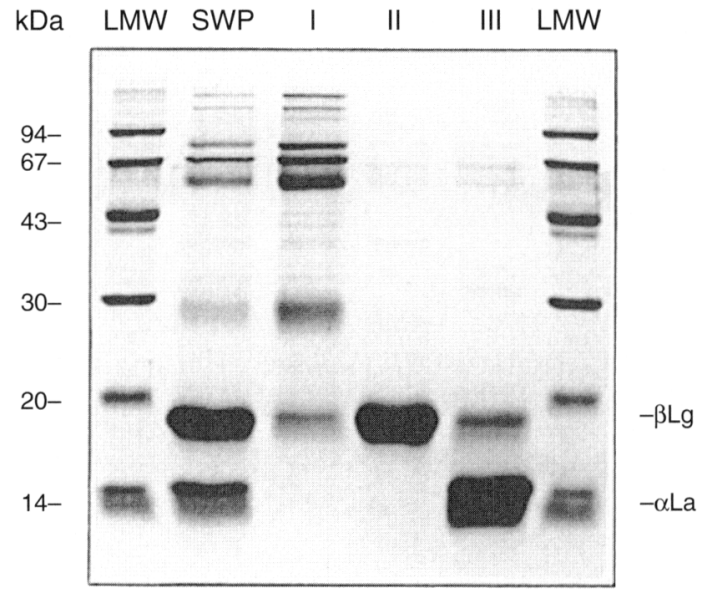

Fig. 2. (a) AcA 44 column $(5 \mathrm{~cm} \times 90 \mathrm{~cm})$ chromatography of $1 \mathrm{~g}$ soluble whey proteins (SWP) with $100 \mathrm{mmol}$ ammonium bicarbonate $\mathrm{I}^{-1}$ at $50 \mathrm{ml} \mathrm{h}^{-1}$. (b) SDS-PAGE of reduced samples of SWP sub-fractions after AcA 44 chromatography. LMW: molecular mass markers. $\alpha$ La: $\alpha$-lactalbumin; $\beta \mathrm{Lg}$ : $\beta$-lactoglobulin.

The NPC fraction was found to contain only caseins and a very small amount of $\beta$-lactoglobulin, whereas the MF fraction was almost devoid of caseins and UF lacked proteins. SWP subfractions were purified by size exclusion chromatography and characterized by SDS-PAGE (Fig. 2).

The NPC fraction diluted in UF (NPC/UF) or in MF (NPC/MF) produced a strong dose-dependent increase in the lipase activity of BUS relative to the effects of UF or MF alone, respectively (Fig. 3a). The initial concentration of NPC in NPC/UF or NPC/MF was $25 \mathrm{mg} \mathrm{ml}^{-1}$ as in milk and, therefore, even at concentrations 10-1000-fold lower than that in milk $\left(25 \mu \mathrm{g}-2.5 \mathrm{mg} \mathrm{ml}{ }^{-1}\right)$, NPC provoked a 3-7-fold increase in the lipase activity of BUS. MF, but not UF, also increased the lipase activity of BUS but was less efficient than NPC when compared on the basis of their relative concentrations in milk. Nevertheless, on a protein content basis, NPC/UF, NPC/MF and MF exhibited identical efficiencies $\left(r^{2}=0.979\right)$ in potentiating BUS lipase activity (Fig. 3b). These effects could be observed with protein concentrations as low as $0.01 \mathrm{mg} \mathrm{ml} \mathrm{m}^{-1}$. A maximum augmentation of BUS lipase activity in olive oil emulsion was found with milk protein 

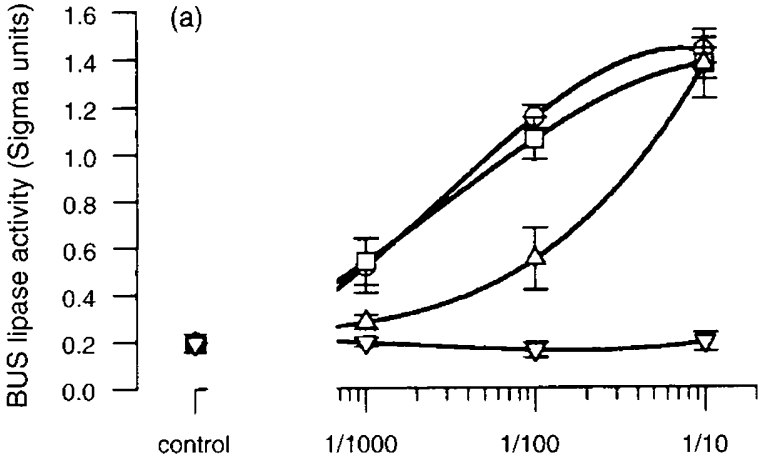

Dilution of milk fractions in olive oil

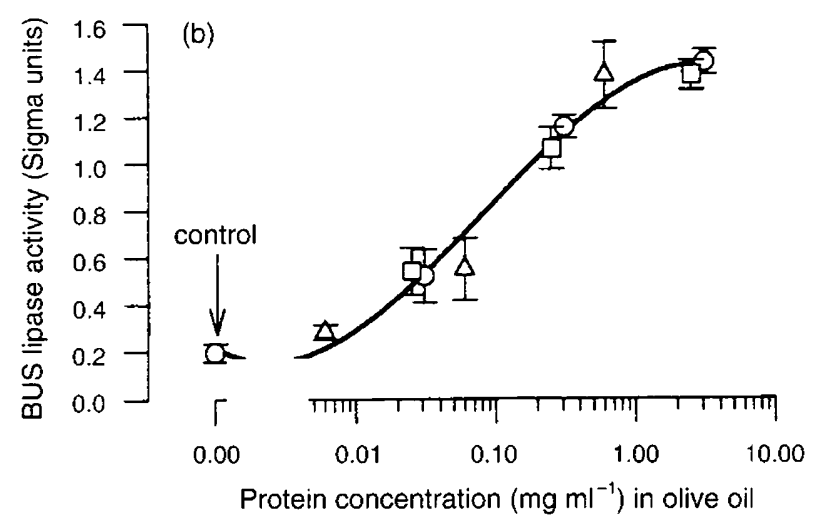

Fig. 3. Lipase activity of bulbourethral gland secretion (BUS) $(5 \mu \mathrm{g}$ in $7.5 \mathrm{ml}$ ) in the presence of native phosphocaseinate fraction/ microfiltrate (NPC/MF, O), NPC/ultrafiltrate fraction (NPC/UF, $\square$ ), microfiltrate (MF, $\triangle$ ) or UF $(\nabla)$ in olive oil emulsion as functions of (a) dilutions of their original concentration milk or (b) their protein concentration. The experiment was conduced in duplicate on three different days. Data were pooled and each value represents mean $\pm \mathrm{SD}$ $(n=6)$.

concentrations higher than $0.5 \mathrm{mg} \mathrm{ml}^{-1}$. These results show that both phosphocaseinate and soluble whey proteins from milk increase the lipase activity of BUS, whereas the soluble low molecular weight components do not.

For determining whether there was some specificity among milk proteins in potentiating BUS lipase activity, the influence on the lipase activity of BUS of increasing doses of NPC. individual caseins, SWP, subfractions from SWP and various proteins and glycoproteins was examined. NPC, as well as $\alpha$ and $\beta$-casein (the major caseins in milk), provoked a strong dose-dependent increase in the BUS lipase activity at protein concentrations between 0.01 and $0.5 \mathrm{mg} \mathrm{ml}^{-1}$ and their dose-response curves were superimposed $\left(r^{2}=0.984\right)$ (Fig. 4a). In contrast, $\kappa$-casein was weakly active. The major protein purified from SWP (Fig. 2), $\beta$-lactoglobulin, was highly efficient in increasing BUS lipase activity between 0.01 and $0.5 \mathrm{mg}$ $\mathrm{ml}^{-1}$ (Fig. 4b). Its effect was dose-dependent and similar to that observed with SWP $\left(r^{2}=0.999\right)$, whereas $\alpha$-lactalbumin and high molecular mass whey proteins (Fig. 2) were inactive in this respect. Almost all the other proteins ( $\beta$-casein, serum albumin) and glycoproteins (apo-transferrin, ovomucoid)
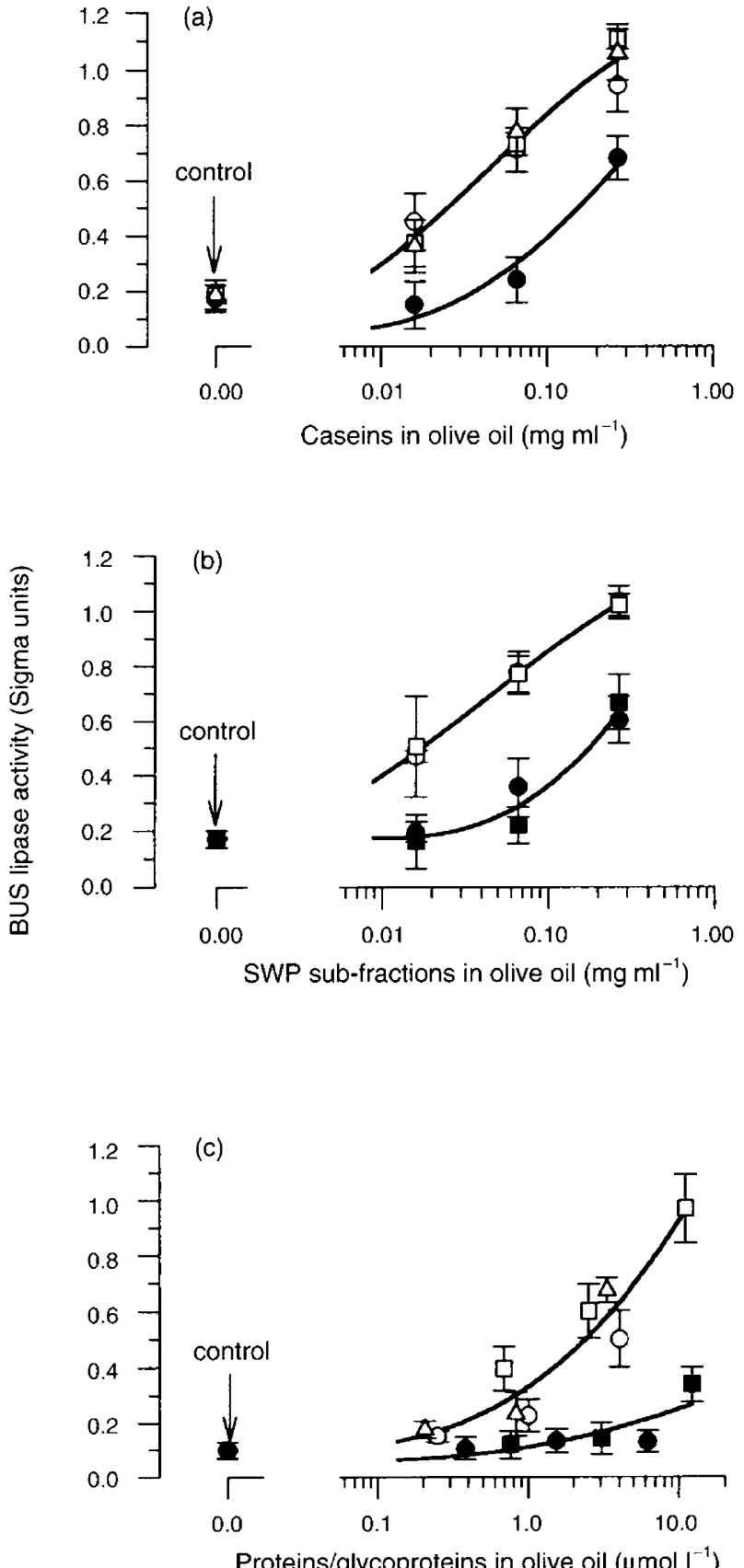

Fig. 4. Effects of increasing doses of (a) individual $\alpha_{-}(\square), \beta-(\triangle)$ and $\kappa$-caseins (O) (native phosphocaseinate fraction: $O$ ); (b) soluble whey proteins (SWP) subfractions (SWP: O; SWP-I: O; SWP-II: $\square$; SWP-III: $\mathbf{\square}$ ) obtained by size exclusion chromatography; or (c) pure proteins ( $\beta$-casein: $\square$; serum albumin: $\bigcirc$ ) or glycoproteins (apotransferrin: $\triangle$; ovomucoid: $\mathbf{\square}$; $\alpha$-acid glycoprotein (orosomucoid): -) in olive oil emulsion on the lipase activity of bulbourethral gland secretion (BUS) ( $5 \mu \mathrm{g}$ in $7.5 \mathrm{ml}$ ). Expts (a) and (b) were conducted in triplicate and Expt (c) in duplicate on two different days. Data were pooled and each value represents mean $\pm \mathrm{SD}$.

tested, except $\alpha 1$-acid glycoprotein, induced a dose-dependent increase in the lipase activity of BUS at concentrations between 0.01 and $0.5 \mathrm{mg} \mathrm{ml}^{-1}$. $\beta$-casein was found to be the most efficient in this respect, followed by transferrin, albumin and 
Table 2. Effects of bulbourethral gland secretion (BUS) on goat sperm quality parameters in skimmed milk, native phosphocaseinate fraction/ultrafiltrate fraction (NPC/UF), microfiltrate (MF) or UF diluents

\begin{tabular}{|c|c|c|c|c|c|}
\hline Diluent & $\begin{array}{c}\text { BUS } \\
\left(\mu \mathrm{g} \mathrm{ml}^{-1}\right)\end{array}$ & $\begin{array}{c}\text { Motile } \\
\text { spermatozoa } \\
(\%)\end{array}$ & $\begin{array}{l}\text { Quality of } \\
\text { movement }\end{array}$ & $\begin{array}{c}\text { Undamaged } \\
\text { acrosomes } \\
(\%)\end{array}$ & $\begin{array}{c}\text { Live } \\
\text { spermatozoa } \\
(\%)\end{array}$ \\
\hline \multirow[t]{2}{*}{ Skimmed milk } & 0 & $64.4 \pm 3.6^{\mathrm{a}}$ & $3.4 \pm 0.2^{\mathrm{ab}}$ & $84.7 \pm 5.6^{a}$ & $81.1 \pm 3.4^{\mathrm{ab}}$ \\
\hline & 50 & $33.8 \pm 6.1^{\mathrm{cd}}$ & $1.4 \pm 0.1^{\mathrm{d}}$ & $55.8 \pm 11.6^{b}$ & $41.3 \pm 5.5^{c}$ \\
\hline \multirow[t]{2}{*}{ NPC/UF } & 0 & $60.6 \pm 4.5^{\mathrm{ab}}$ & $3.5 \pm 0.2^{\mathrm{a}}$ & $80.6 \pm 5.5^{\mathrm{ab}}$ & $79.1 \pm 3.2^{\mathrm{ab}}$ \\
\hline & 50 & $24.4 \pm 6.5^{\mathrm{d}}$ & $1.4 \pm 0.1^{\mathrm{d}}$ & $69.9 \pm 8.0^{\mathrm{ab}}$ & $67.8 \pm 3.8^{\mathrm{b}}$ \\
\hline \multirow[t]{2}{*}{ MF } & 0 & $51.9 \pm 7.0^{\text {ad }}$ & $2.7 \pm 0.2^{\mathrm{bc}}$ & $83.0 \pm 5.9^{\mathrm{ab}}$ & $79.6 \pm 3.7^{\mathrm{ab}}$ \\
\hline & 50 & $55.0 \pm 6.5^{a b c}$ & $2.6 \pm 0.2^{c}$ & $84.1 \pm 5.6^{a}$ & $81.3 \pm 3.6^{\mathrm{ab}}$ \\
\hline \multirow[t]{2}{*}{ UF } & 0 & $41.9 \pm 4.5^{\mathrm{bd}}$ & $2.9 \pm 0.3^{\mathrm{abc}}$ & $82.2 \pm 5.4^{\mathrm{ab}}$ & $84.0 \pm 2.3^{\mathrm{a}}$ \\
\hline & 50 & $46.3 \pm 3.3^{\text {ad }}$ & $2.6 \pm 0.2^{c}$ & $81.3 \pm 5.8^{a b}$ & $82.4 \pm 2.0^{\mathrm{a}}$ \\
\hline
\end{tabular}

Each value represents the mean \pm SEM of eight replicates.

All diluents contained $0.2 \%$ D-glucose. Measurements were performed after $30 \mathrm{~min}$ incubation at $37^{\circ} \mathrm{C}$.

${ }^{a b c d}$ Values in the same column with different superscripts differ significantly (confidence intervals multiple comparison: $P<0.05$ ).

ovomucoid on the basis of weight or molarity (Fig. 4c). The highly glycosylated glycoproteins, such as ovomucoid and $\alpha 1$-acid glycoprotein, caused very moderate or no increase at all in the lipase activity of BUS at concentrations below $10 \mu \mathrm{mol} \mathrm{l}^{-1}$.

These data suggest that the potentiating effect of proteins on BUS lipase activity is largely, but not totally, nonspecific since nonglycosylated proteins or glycoproteins with low carbohydrate content appear to be more efficient than highly glycosylated glycoproteins. The data also show that the favourable effect of milk on BUS lipase activity is not due to a particular protein but is a function of the total protein concentration in the milk.

\section{Identification of milk component(s) mediating the sperm-deteriorating activity of BUSgp60}

The effects of BUS on sperm quality parameters at $37^{\circ} \mathrm{C}$ were studied in skimmed milk, NPC/UF, MF and UF diluents. Among different parameters, multifactor analysis of variance (diluent $\times$ BUS treatment) revealed differences between diluents only when the percentage of live spermatozoa was assessed $(P<0.0001)$. However, treatment with BUS affected all parameters $(P<0.05)$. There was a significant $(P<0.001)$ interaction between both variables except in the percentage of undamaged acrosomes $(P>0.05)$. Among the diluents tested (Table 2), significant deleterious effects of BUS on the sperm quality parameters were evidenced only in those containing skimmed milk or NPC/UF ( $P<0.05$ ).

Sperm quality parameters were analysed in the presence of BUS at $37^{\circ} \mathrm{C}$ in KRPG diluent containing NPC or SWP either at $25 \mathrm{mg} \mathrm{ml}^{-1}$ (normal casein concentration in milk) or at $6 \mathrm{mg}$ $\mathrm{ml}^{-1}$ (normal whey protein concentration in milk) to determine which milk protein fraction(s) mediate the spermdeteriorating activity of BUSgp60. Multifactor analysis of variance (diluents $\times$ BUS treatment) of the data showed significant differences between diluents $(P<0.05)$ or BUS treatment $(P<0.01)$. Interaction between both variables was also detected $(P<0.05)$. BUS produced a significant decrease in the sperm quality parameters only in the presence of NPC at the two concentrations tested $(P<0.01)$, whereas SWP had no effect at any concentration $(P>0.05)$ (Table 3$)$. Therefore, both the NPC and SWP fractions potentiate the activity of the BUSgp60 lipase in a dose-dependent manner but only the NPC fraction mediates the sperm-deteriorating activity of BUS. This finding suggests that the NPC fraction, but not the SWP fraction, contains substrate(s) for the BUSgp60 lipase. In keeping with this hypothesis, residual triglycerides were found only in the NPC fraction (Table 4) and can indeed be hydrolysed by the BUS lipase (Fig. 5), suggesting that the mediator of the sperm-deteriorating action of BUS is a product of the hydrolysis of triglycerides (free fatty acids and mono- and di-glycerides).

Identification of the mediator(s) of the sperm-deteriorating action of the BUSgp60 lipase in milk diluents

The effects of increasing doses of palmitic acid (major saturated fatty acid in milk) or oleic acid (the major cisunsaturated fatty acid in milk) on the sperm quality parameters were examined at $37^{\circ} \mathrm{C}$ in $10 \%$ dehydrated skimmed milk diluent and compared with the effects produced by BUS. High concentrations $\left(10-40 \mathrm{mmol} \mathrm{l}^{-1}\right)$ of palmitic acid decrease the $\mathrm{pH}$ of milk and this is accompanied by a significant dosedependent decrease in the percentage of motile spermatozoa and sperm movement quality $(P<0.01)$, whereas acrosomes remain intact and the percentage of live spermatozoa are unaffected $(P>0.05)$ (Table 5). In contrast, when milk diluents containing palmitic acid were adjusted to the $\mathrm{pH}$ of milk ( $\mathrm{pH}$ 6.5) before incubation, the deleterious effects of this fatty acid on sperm motility parameters were not observed $(P>0.05)$. These effects were different from those produced by BUS that induced a strong decrease in the sperm quality parameters $(P<0.01)$ without modifying milk $\mathrm{pH}$. Oleic acid produces a dose-dependent deterioration of all sperm quality parameters $(P<0.01)$ at much lower concentrations $(0.15-$ $2.5 \mathrm{mmol} \mathrm{I}^{-1}$ ) than palmitic acid without affecting milk $\mathrm{pH}$ (Table 5). Maximum decreases in each parameter relative to 
Table 3. Effects of bulbourethral gland secretion (BUS) on goat sperm quality parameters in the presence of two concentrations of native phosphocaseinate fraction (NPC) or soluble whey proteins (SWP)

\begin{tabular}{|c|c|c|c|c|c|}
\hline Diluent & $\begin{array}{c}\text { BUS } \\
\left(\mu \mathrm{g} \mathrm{ml}^{-1}\right)\end{array}$ & $\begin{array}{c}\text { Motile } \\
\text { spermatozoa } \\
(\%)\end{array}$ & $\begin{array}{l}\text { Quality of } \\
\text { movement }\end{array}$ & $\begin{array}{c}\text { Undamaged } \\
\text { acrosomes } \\
(\%)\end{array}$ & $\begin{array}{c}\text { Live } \\
\text { spermatozoa } \\
(\%)\end{array}$ \\
\hline $\mathrm{NPC}^{*}$ & 0 & $73.0 \pm 5.8^{a}$ & $3.6 \pm 0.2^{a}$ & $86.5 \pm 2.4^{a}$ & $83.3 \pm 1.7^{\mathrm{a}}$ \\
\hline$\left(25 \mathrm{mg} \mathrm{ml}^{-1}\right)$ & 50 & $15.0 \pm 0.1^{b}$ & $1.1 \pm 0.1^{b}$ & $73.0 \pm 2.9^{b}$ & $56.8 \pm 4.9^{b}$ \\
\hline $\mathrm{NPC}$ & 0 & $72.0 \pm 5.8^{\mathrm{a}}$ & $3.4 \pm 0.3^{\mathrm{a}}$ & $85.3 \pm 1.5^{\mathrm{a}}$ & $82.5 \pm 2.4^{\mathrm{a}}$ \\
\hline$\left(6 \mathrm{mg} \mathrm{ml}^{-1}\right)$ & 50 & $27.0 \pm 4.6^{\mathrm{b}}$ & $1.5 \pm 0.2^{b}$ & $81.5 \pm 2.6^{\mathrm{ab}}$ & $57.2 \pm 6.9^{b}$ \\
\hline SWP & 0 & $66.0 \pm 2.9^{a}$ & $3.4 \pm 0.2^{\mathrm{a}}$ & $86.3 \pm 2.3^{\mathrm{a}}$ & $87.3 \pm 0.5^{a}$ \\
\hline$\left(25 \mathrm{mg} \mathrm{ml}^{-1}\right)$ & 50 & $63.0 \pm 5.8^{\mathrm{a}}$ & $3.3 \pm 0.3^{\mathrm{a}}$ & $86.0 \pm 1.4^{\mathrm{a}}$ & $87.3 \pm 1.7^{\mathrm{a}}$ \\
\hline SWP* & 0 & $82.0 \pm 2.0^{\mathrm{a}}$ & $4.0 \pm 0.1^{\mathrm{a}}$ & $86.5 \pm 1.8^{a}$ & $83.9 \pm 1.2^{\mathrm{a}}$ \\
\hline$\left(6 \mathrm{mg} \mathrm{ml}^{-1}\right)$ & 50 & $79.0 \pm 2.9^{\mathrm{a}}$ & $3.9 \pm 0.1^{\mathrm{a}}$ & $83.2 \pm 1.6^{\mathrm{ab}}$ & $85.6 \pm 2.0^{\mathrm{a}}$ \\
\hline
\end{tabular}

Each value represents the mean \pm SEM of five replicates.

*Concentration in milk.

Measurements were performed after $60 \mathrm{~min}$ incubation at $37^{\circ} \mathrm{C}$ in an isotonic saline solution, KRPG (10 mmol sodium phosphate $1^{-1}, \mathrm{pH} 7.0$, containing $123 \mathrm{mmol} \mathrm{NaCl} \mathrm{l^{-1 }}, 5 \mathrm{mmol} \mathrm{KCl} \mathrm{l^{-1 }}, 3 \mathrm{mmol} \mathrm{CaCl}_{2} \mathrm{I}^{-1}, 1 \mathrm{mmol} \mathrm{MgSO}_{4} \mathrm{I}^{-1}$ and $0.2 \% \alpha-\mathrm{D}-$ glucopyranose), containing the proteins at the concentrations indicated.

${ }^{a b}$ Values in the same column with different superscripts differ significantly (confidence intervals multiple comparison: $P<0.01$ ).

Table 4. Triglyceride concentration in milk fractions

\begin{tabular}{lc}
\hline $\begin{array}{l}\text { Milk } \\
\text { fraction }\end{array}$ & $\begin{array}{c}\text { Concentration } \\
\left.\text { (mean } \pm \mathrm{SD} ; \mathrm{mg} \mathrm{ml}^{-1}\right)\end{array}$ \\
\hline Skimmed milk & $0.702 \pm 0.180$ \\
$(n=6)$ \\
NPC/UF & $0.523 \pm 0.200$ \\
$(n=5)$ \\
MF & $<0.140^{*}$ \\
& $(n=6)$ \\
UF & $<0.140^{*}$ \\
& $(n=6)$
\end{tabular}

*Detection limit.

NPC/UF, native phosphocaseinate fraction/ultrafiltrate fraction; MF, microfiltrate.

their corresponding control values were observed at concentrations higher than $1.25 \mathrm{mmol}$ oleic acid $\mathrm{I}^{-1}$. These data suggest that oleic acid released from residual triglycerides in skimmed milk is responsible for the deleterious effect of BUS on goat spermatozoa.

The ability of BUS to hydrolyse triolein was checked over $60 \mathrm{~min}$ at $37^{\circ} \mathrm{C}$ in $1 \mathrm{ml}$ of either KRPG or SWP diluent $(25 \mathrm{mg}$ $\mathrm{ml}^{-1}$ in KRPG) to confirm that the deterioration of goat spermatozoa promoted by BUSgp60 lipase was due to the hydrolysis of triglycerides containing oleic acid. The production of free oleic acid from triolein under hydrolysis by the BUS lipase was demonstrated by thin layer chromatography. Next, the effects of BUS on the sperm quality parameters were analysed after incubation at $37^{\circ} \mathrm{C}$ in SWP diluent containing increasing doses of triolein. Multifactor analysis of variance (triolein concentration $\times$ BUS treatment) of the data revealed differences between the different triolein concentrations used $(P<0.0001)$. A BUS-dependent effect was also observed $(P<0.001)$ and an interaction between both variables was established $(P<0.0001)$. A dose-dependent detrimental effect of triolein on spermatozoa occurred only when BUS was present $(P<0.05)$, without any significant change in $\mathrm{pH}$ (Table 6).

\section{Discussion}

BUSgp60 lipase produces a decrease in the percentage of motile spermatozoa, deterioration of sperm movement quality, breakage of acrosomes and cellular death of goat epididymal spermatozoa diluted in skimmed milk during incubation at $37^{\circ} \mathrm{C}$. These effects are not accompanied by a decrease in the $\mathrm{pH}$ of milk (Pellicer-Rubio et al., 1997). The present results provide evidence for an indirect mechanism in goat sperm deterioration by BUSgp60 lipase with the use of skimmed milk-based extenders involving the hydrolysis of residual triglycerides and the subsequent release of oleic acid which is toxic for goat spermatozoa.

Among all milk fractions, only the native phosphocaseinate (NPC) was found to play the same permissive role as milk in the sperm-deteriorating activity of BUS. However, it appeared that NPC, as well as SWP, potentiated the lipolytic activity of the BUS lipase. Moreover, highly purified proteins $(\alpha-, \beta-, \kappa-$ caseins, $\beta$-lactoglobulin, transferrin and albumin) were also found to enhance the lipase activity of BUS, supporting a nonspecific positive effect of these proteins on the enzyme activity. Both caseins and soluble whey proteins are surfaceactive agents (Leman and Kinsella, 1989) and may, therefore, enhance the lipolytic action of BUS lipase either by increasing the accessibility of the substrate, by means of their emulsifying properties, or by facilitating the adsorption and desorption of the lipase at the interface, thus preventing its irreversible denaturation. Since hydrophobic interactions are involved in these events (Leman and Kinsella, 1989), it was not surprising to find that the glycoproteins with the highest carbohydrate contents (ovomucoid and $\alpha_{1}$-acid glycoprotein) were not able to increase the lipase activity of BUS. Surface-active agents 


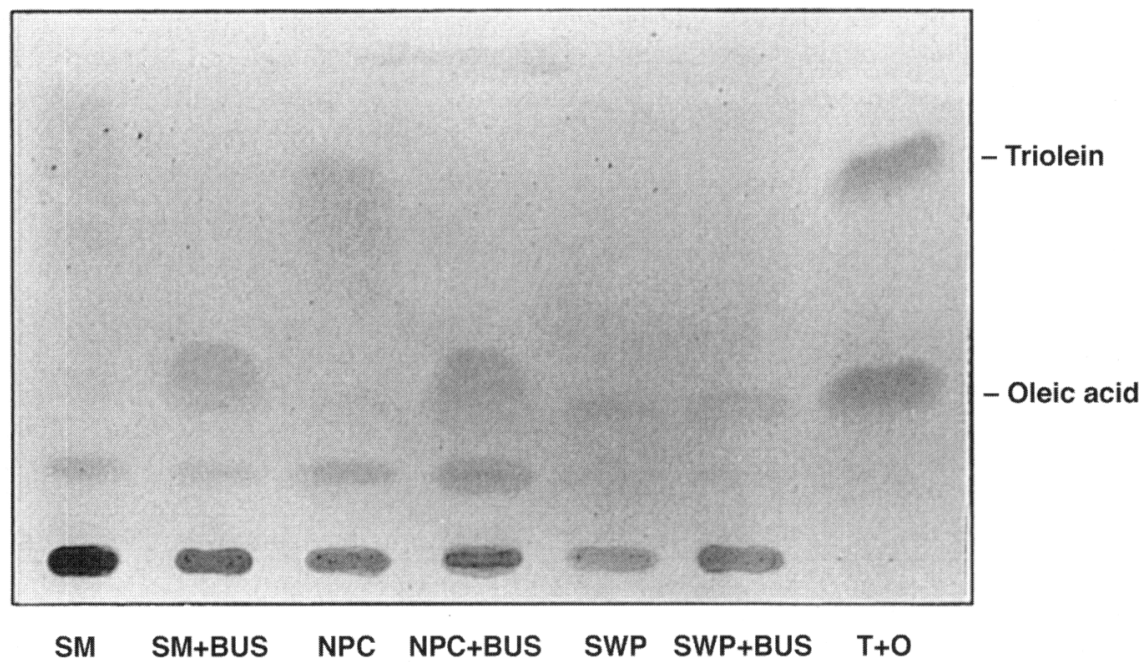

Fig. 5. Thin layer chromatography of lipid extract from $1 \mathrm{ml}$ skimmed milk (SM) or from $25 \mathrm{mg}$ native phosphocaseinate fraction (NPC) or soluble whey proteins (SWP) in $1 \mathrm{ml}$ KRPG (10 mmol sodium phosphate $1^{-1}, \mathrm{pH} 7.0$, containing $123 \mathrm{mmol} \mathrm{NaCl} \mathrm{l} \mathrm{l}^{-1}, 5 \mathrm{mmol} \mathrm{KCl} \mathrm{l^{-1 }}$, $3 \mathrm{mmol} \mathrm{CaCl} \mathrm{l}^{-1}, 1 \mathrm{mmol} \mathrm{MgSO}_{4} \mathrm{l}^{-1}$ and $0.2 \% \alpha$-D-glucopyranose), after $60 \mathrm{~min}$ incubation at $37^{\circ} \mathrm{C}$ in the absence (control sample) or presence of $50 \mu \mathrm{g}$ bulbourethral gland secretion (BUS). A mixture of $100 \mu \mathrm{g}$ pure triolein and $100 \mu \mathrm{g}$ pure oleic acid $(\mathrm{T}+\mathrm{O})$ was used as a reference.

Table 5. Effects of bulbourethral gland secretion (BUS), palmitic acid or oleic acid on quality parameters of goat spermatozoa

\begin{tabular}{|c|c|c|c|c|c|}
\hline Diluent & $\mathrm{pH}^{*}$ & $\begin{array}{c}\text { Motile } \\
\text { spermatozoa } \\
(\%)\end{array}$ & $\begin{array}{l}\text { Quality of } \\
\text { movement }\end{array}$ & $\begin{array}{l}\text { Undamaged } \\
\text { acrosomes } \\
(\%)\end{array}$ & $\begin{array}{c}\text { Live } \\
\text { spermatozoa } \\
(\%)\end{array}$ \\
\hline $10 \%$ Dehydrated skimmed milk (control) & 6.40 & $68.8 \pm 2.4^{\mathrm{a}}$ & $4.0 \pm 0.2^{\mathrm{a}}$ & $90.4 \pm 1.2^{\mathrm{a}}$ & $74.6 \pm 3.8^{\mathrm{a}}$ \\
\hline $10 \%$ Dehydrated skimmed milk $+50 \mu \mathrm{g}$ BUS & 6.36 & $8.8 \pm 3.7^{c}$ & $1.2 \pm 0.2^{\mathrm{c}}$ & $6.1 \pm 2.8^{\mathrm{c}}$ & $5.5 \pm 2.5^{\mathrm{b}}$ \\
\hline \multirow[t]{2}{*}{$10 \mathrm{mmol}$ palmitic acid $\mathrm{l}^{-1}$} & 6.14 & $56.3 \pm 5.5^{\mathrm{a}}$ & $2.5 \pm 0.2^{\mathrm{b}}$ & $87.5 \pm 2.9^{\mathrm{a}}$ & $69.0 \pm 5.1^{\mathrm{a}}$ \\
\hline & $6.47^{+}$ & $66.3 \pm 5.9^{\mathrm{a}}$ & $4.0 \pm 0.2^{\mathrm{a}}$ & $82.6 \pm 2.0^{\mathrm{ab}}$ & $73.0 \pm 3.3^{\mathrm{a}}$ \\
\hline \multirow[t]{2}{*}{20 mmol palmitic acid $1^{-1}$} & 5.99 & $45.0 \pm 2.8^{b}$ & $1.9 \pm 0.1^{\mathrm{bc}}$ & $87.8 \pm 2.8^{\mathrm{a}}$ & $69.4 \pm 5.7^{\mathrm{a}}$ \\
\hline & $6.41^{\dagger}$ & $63.8 \pm 3.7^{a}$ & $4.1 \pm 0.1^{\mathrm{a}}$ & $87.5 \pm 2.5^{\mathrm{a}}$ & $71.3 \pm 4.5^{\mathrm{a}}$ \\
\hline \multirow[t]{2}{*}{$40 \mathrm{mmol}$ palmitic acid $\mathrm{l}^{-1}$} & 5.62 & $20.0 \pm 4.5^{c}$ & $1.0 \pm 0.1^{\mathrm{c}}$ & $70.5 \pm 5.4^{\mathrm{b}}$ & $53.3 \pm 10.5^{\mathrm{a}}$ \\
\hline & $6.35^{\dagger}$ & $61.3 \pm 4.2^{\mathrm{a}}$ & $3.8 \pm 0.1^{\mathrm{a}}$ & $83.1 \pm 2.5^{\mathrm{ab}}$ & $69.1 \pm 1.8^{\mathrm{a}}$ \\
\hline $10 \%$ Dehydrated skimmed milk (control) & 6.53 & $51.3 \pm 3.1^{\mathrm{a}}$ & $3.8 \pm 0.1^{\mathrm{a}}$ & $61.3 \pm 3.6^{\mathrm{a}}$ & $46.8 \pm 2.2^{\mathrm{a}}$ \\
\hline $10 \%$ Dehydrated skimmed milk $+50 \mu \mathrm{g}$ BUS & 6.45 & $5.3 \pm 1.8^{\mathrm{d}}$ & $0.6 \pm 0.1^{\text {de }}$ & $32.0 \pm 4.3^{\mathrm{bc}}$ & $2.6 \pm 0.9^{c}$ \\
\hline $0.15 \mathrm{mmol}$ oleic acid $\mathrm{l}^{-1}$ & 6.53 & $50.0 \pm 4.5^{\mathrm{a}}$ & $3.8 \pm 0.1^{\mathrm{a}}$ & $61.8 \pm 3.7^{\mathrm{a}}$ & $46.9 \pm 3.3^{\mathrm{a}}$ \\
\hline $0.31 \mathrm{mmol}$ oleic acid $\mathrm{l}^{-1}$ & 6.52 & $37.5 \pm 1.4^{\mathrm{ab}}$ & $3.0 \pm 0.2^{\mathrm{ab}}$ & $62.1 \pm 3.4^{\mathrm{a}}$ & $32.9 \pm 2.0^{\mathrm{ab}}$ \\
\hline $0.62 \mathrm{mmol}^{0}$ oleic acid $\mathrm{I}^{-1}$ & 6.50 & $30.0 \pm 4.5^{\mathrm{bc}}$ & $2.1 \pm 0.2^{\mathrm{bc}}$ & $49.1 \pm 3.6^{\mathrm{ab}}$ & $28.6 \pm 3.5^{\mathrm{b}}$ \\
\hline $1.25 \mathrm{mmol}$ oleic acid $1^{-1}$ & 6.49 & $18.8 \pm 3.7^{\mathrm{cd}}$ & $1.5 \pm 0.2^{\mathrm{cd}}$ & $31.6 \pm 6.5^{\mathrm{bc}}$ & $11.3 \pm 3.0^{\mathrm{c}}$ \\
\hline $2.50 \mathrm{mmol}$ oleic acid $\mathrm{I}^{-1}$ & 6.49 & $2.0 \pm 1.0^{d}$ & $0.5 \pm 0.1^{\mathrm{e}}$ & $16.6 \pm 2.1^{d}$ & $0.6 \pm 0.3^{c}$ \\
\hline
\end{tabular}

Each value represents the mean \pm SEM of four replicates.

${ }^{*} \mathrm{pH}$ measured after incubation $\left(60 \mathrm{~min}\right.$ incubations at $\left.37^{\circ} \mathrm{C}\right) ;{ }^{\dagger} \mathrm{pH}$ of diluents adjusted to 6.5 before incubation.

${ }^{a b c d e}$ Values in the same column with different superscripts differ significantly (confidence intervals multiple comparison: $P<0.01$ ).

such as bile salts, at concentrations below their micellar critical concentration, and proteins such as albumin or colipase, in the absence of bile salts, have also been shown to increase the apparent hydrolysis rate of pig pancreatic lipase, providing protection to lipase against interfacial inactivation (Bogström and Erlanson, 1973; Momsen and Brockman, 1976; Verger et al., 1977). Moreover, bovine serum albumin and $\beta$-lactoglobulin, but not $\alpha$-lactalbumin, potentiate the activity of other lipases such as lamb pharyngeal pregastric lipase (Pérez et al., 1992).

Since all milk protein fractions potentiated the BUS lipase activity but only the NPC fraction mediated the spermdeteriorating activity of BUS, it was first hypothesized that the lipase activity was not responsible for deterioration of sperm viability. However, highly purified BUSgp60, as well as pig pancreatic lipase, was able to reproduce the same deleterious 
Table 6. Effects of bulbourethral gland secretion (BUS) on quality parameters of goat spermatozoa with increasing concentrations of triolein

\begin{tabular}{|c|c|c|c|c|c|c|}
\hline $\begin{array}{l}\text { Triolein } \\
\left(\mathrm{mg} \mathrm{ml}^{-1}\right)\end{array}$ & $\begin{array}{c}\text { BUS } \\
\left(\mu \mathrm{g} \mathrm{ml}^{-1}\right)\end{array}$ & $\mathrm{pH}^{*}$ & $\begin{array}{c}\text { Motile } \\
\text { spermatozoa } \\
(\%)\end{array}$ & $\begin{array}{l}\text { Quality of } \\
\text { movement }\end{array}$ & $\begin{array}{l}\text { Undamaged } \\
\text { acrosomes } \\
(\%)\end{array}$ & $\begin{array}{c}\text { Live } \\
\text { spermatozoa } \\
(\%)\end{array}$ \\
\hline \multirow[t]{2}{*}{0} & 0 & 6.84 & $75.0 \pm 2.0^{a}$ & $4.3 \pm 0.1^{\mathrm{a}}$ & $94.3 \pm 1.1^{\mathrm{a}}$ & $82.5 \pm 2.3^{a}$ \\
\hline & 50 & 6.84 & $72.5 \pm 4.3^{\mathrm{a}}$ & $4.0 \pm 0.1^{a}$ & $95.6 \pm 0.4^{\mathrm{a}}$ & $87.1 \pm 1.2^{\mathrm{a}}$ \\
\hline 1.5 & 0 & 6.85 & $71.3 \pm 2.4^{\mathrm{a}}$ & $4.3 \pm 0.1^{\mathrm{a}}$ & $91.1 \pm 2.2^{\mathrm{a}}$ & $85.2 \pm 2.1^{\mathrm{a}}$ \\
\hline$\left(1.7 \mathrm{mmol} \mathrm{l}^{-1}\right)$ & 50 & 6.84 & $66.3 \pm 2.4^{\mathrm{ab}}$ & $3.9 \pm 0.1^{a}$ & $94.3 \pm 1.8^{\mathrm{a}}$ & $85.7 \pm 2.1^{a}$ \\
\hline 3 & 0 & 6.86 & $75.0 \pm 0.1^{\mathrm{a}}$ & $4.4 \pm 0.1^{\mathrm{a}}$ & $93.1 \pm 0.8^{\mathrm{a}}$ & $84.6 \pm 1.8^{a}$ \\
\hline$\left(3.4 \mathrm{mmol} \mathrm{I}^{-1}\right)$ & 50 & 6.79 & $56.3 \pm 3.1^{\mathrm{b}}$ & $2.3 \pm 0.1^{b}$ & $88.5 \pm 2.5^{\mathrm{a}}$ & $83.5 \pm 3.1^{\mathrm{a}}$ \\
\hline 6 & 0 & 6.86 & $75.0 \pm 2.0^{a}$ & $4.3 \pm 0.1^{a}$ & $94.4 \pm 0.7^{\mathrm{a}}$ & $83.5 \pm 2.4^{a}$ \\
\hline$\left(6.8 \mathrm{mmol} \mathrm{I}^{-1}\right)$ & 50 & 6.73 & $8.8 \pm 5.9^{c}$ & $0.6 \pm 0.4^{c}$ & $24.1 \pm 17.1^{b}$ & $12.0 \pm 8.9^{b}$ \\
\hline
\end{tabular}

Each value represents the mean \pm SEM of four replicates.

Measurements were performed after $60 \mathrm{~min}$ incubation at $37^{\circ} \mathrm{C}$ in an isotonic saline solution, $\mathrm{KRPG}$, containing $25 \mathrm{mg}$ soluble whey proteins (SWP) $\mathrm{ml}^{-1}$

* pH measured after incubation.

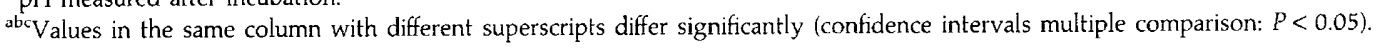

effects as BUS on goat spermatozoa diluted in skimmed milk. Triglycerides were found in substantial amounts only in the NPC fraction. Moreover, triolein promoted a clear dosedependent deterioration of sperm quality parameters in the presence of BUS but not in its absence. Therefore, residual triglycerides from skimmed milk were identified as responsible for promoting sperm deterioration in the presence of BUS. Milk not only provides triglycerides that are substrates for the BUSgp 60 lipase but also many different proteins that potentiate the activity of the enzyme.

Nunes (1982) and Corteel (1990) have suggested that an enzyme from BUS would act on milk component(s) to produce agents that would be toxic for goat spermatozoa. In keeping with this view, the present study showed that the BUS lipase is able to hydrolyse both triolein and milk triglycerides into free fatty acids. Moreover, oleic acid, which is the major fatty acid (30-40\%) among milk triglycerides (Veisseyre, 1980), exerted a clear dose-dependent adverse effect on goat spermatozoa to a similar extent to that of BUS in milk diluents. In contrast, palmitic acid (the major saturated fatty acid in milk triglycerides: $25-29 \%$ ), even at 20 -fold higher concentrations, did not exert such effects. In addition, the concentration dependence of the detrimental effects of triolein on goat spermatozoa (range, 2-7 $\mathrm{mmol} \mathrm{l}^{-1}$ ) in the presence of BUS is compatible with that of oleic acid (range, $0.6-2.5 \mathrm{mmol}^{-1}$ ). Nevertheless, it cannot be ruled out that either mono-olein or di-olein, or both, which also derive from triolein under lipase action, also play a role through fusogenic action (Holt and Dott, 1980). The concentrations of these derivatives in the experimental conditions of the present study were not known. However, it may be tentatively concluded that the negative effects of BUS on goat spermatozoa in skimmed milk-based extenders were due to the hydrolysis of residual triglycerides giving rise to oleic acid. This would lead to detrimental effects on sperm quality upon cooling, thus reducing their survival after freezing and thawing.

Althrough the presence of milk triglycerides is mandatory for the expression of the sperm-deteriorating activity of BUS, a direct harmful effect of BUSgp60 lipase on goat spermatozoa through the hydrolysis of cell membrane phospholipids, galactolipids or triglycerides cannot be excluded. Indeed. BUSgp60 has been identified as a novel pancreatic lipase-related protein 2 (PLRP2) (Pellicer-Rubio et al., 1997), and PLRP2 enzymes are known to display both phospholipase A (Hjorth et al., 1993; Thirstrup et al., 1994; Carrière et al., 1994; Jennens and Lowe, 1995) and galactolipase activities (Andersson et al., 1996) in addition to their lipase activity. In addition, lipids from goat mature sperm membranes consist of phospholipids (70\%), neutral lipids ( $28 \%$ including triglycerides) and glycolipids ( $2 \%$ ) (Rana et al., 1991). Moreover, phospholipase A activity has been implicated in cell-mediated cytotoxic mechanisms (Frye and Friou, 1975). In addition, Grusby et al. (1990) demonstrated a clear correlation between expression of PLRP2 from mouse cytotoxic lymphocytes and its cytolytic potential. However, phospholipase A appears ineffective in the degradation of phospholipids in intact cell membranes, suggesting that lysis could occur through a two-step process, the first involving an undefined perturbation of the membrane (Frye and Friou, 1975). Therefore, the sperm deterioration probably arises primarily from the action of oleic acid, but a direct hydrolysis of sperm membrane phospholipids may reinforce this action.

The adverse effects of oleic acid on goat spermatozoa could be due to cell membrane damage resulting from its lipid fusogenic activity (Meizel, 1984). Courtens et al. (1984) have shown that BUS promotes membrane fusion events similar to the acrosome reaction in goat epididymal spermatozoa diluted in skimmed milk but not in KRPG buffer. Moreover, oleic acid and other cis-unsaturated FA, but not trans-unsaturated or saturated FA, promote the acrosome reaction in hamster and ram spermatozoa (Meizel and Turner, 1983; Meizel, 1984; Roldán and Fragio, 1993). Nevertheless, at variance with our results, these effects were not accompanied by a deterioration in sperm motility and viability. This could be due to differences in the composition and structure of sperm membranes, between experimental procedures or between species. 
Oleic acid may also promote a premature acrosomal exocytosis and negative effects on motility regulation in goat spermatozoa via protein kinase $C(\mathrm{PKC})$ activation. Indeed, oleic acid and cis-unsaturated FA in general, but not saturated or trans-unsaturated FA, stimulate the $\mathrm{Ca}^{2+}$-independent $(\delta, \varepsilon, \zeta$ and $\eta)$ but also, to a lesser extent, the $\mathrm{Ca}^{2+}$-dependent $(\alpha, \beta \mathrm{I}$, $\beta I I$ and c) PKC isoforms directly in rat brain (Shinomura et al., 1991), human platelets (Khan et al., 1993) and rat vascular smooth muscle cells (Lu et al., 1996). In this respect, $\mathrm{Ca}^{2+}$ dependent $(\alpha, \beta \mathrm{I}, \beta \mathrm{II}$ and $\mathrm{c})$ and $\mathrm{Ca}^{2+}$-independent $(\varepsilon)$ PKC isoforms have also been identified in spermatozoa from rams, bulls (Breitbart et al., 1992; Chaudhry and Casillas, 1992) and humans (Rotem et al., 1990, 1992). Moreover, several lines of evidence show the involvement of sperm PKC activation in the cascade leading to acrosomal exocytosis in bull (Breitbart et al., 1992; Lax et al., 1994; Rubinstein et al., 1995), macaque (Tollner et al., 1995), human (Rotem et al, 1992; Foresta et al., 1995) and giant panda spermatozoa (Sun et al., 1996). In addition, sperm PKC stimulation is also involved in the regulatory mechanisms of flagellar motility, exerting either positive effects in human spermatozoa (Rotem et al., 1990) or negative effects in fowl spermatozoa (Ashizawa et al., 1994).

Oleic acid and other fatty acids have been shown to exert direct regulation of ion channels in a variety of cells (Ordway et al., 1991). To our knowledge, this has not yet been shown in spermatozoa but the effects of oleic acid on sperm viability would be compatible with such a mechanism.

For improving the viability of goat spermatozoa stored frozen in milk based extenders, an alternative method of washing semen could be to inhibit BUSgp60 lipase specifically in seminal plasma. Nevertheless, it must be considered that bulbourethral lipase may play a role in fertility. The work presented here suggests new methods for preserving unwashed goat semen without inhibiting the enzyme. One possibility is the total delipidation of cow milk-based diluents. Moreover, since caseins appear to be the main protective agents of spermatozoa against cold shock (Colas, 1984), a second possibility would be the development of triglyceride-free casein-based diluents. In addition, since milk lipids from various species differ essentially in their fatty acids composition and triacylglycerol structure (Jensen et al., 1990), a third possibility is the use of milk or caseins from species other than the cow.

Bulbourethral gland secretion is also detrimental to the viability of cryopreserved goat sperm in egg-yolk extenders. The egg-yolk coagulating enzyme (EYCE; Roy, 1957), identified as a phosopholipase A (Iritani and Nishikawa, 1972), may catalyse the hydrolysis of egg-yolk lecithin into fatty acids and lysolecithin which are toxic for goat spermatozoa. However, the reported experimental conditions for phospholipase activity measurements do not rule out the possible involvement of a lipase of the PLRP2 type. Therefore, BUSgp60 lipase and EYCE may be related or even identical enzymes, and the use of BUSgp 60 inhibitors for better cryopreservation of unwashed goat semen in egg-yolk diluents should be considered.

The authors are indebted to J. Fauquant and J. L. Maubois (INRA, Milk Technology Laboratory, Rennes, France) for the kind gift of highly purified milk fractions and proteins. M-T. Pellicer-Rubio was supported by a Formación de Personal Investigador (Subprograma de Formación de Postgrado en el Extranjero) fellowship from the Ministerio de Educación y Ciencia, Spain.

\section{References}

Alvarez JG, Lasso J, Blasco L, Nuñez RC, Heyner S, Caballero PP and Storey T (1993) Centrifugation of human spermatozoa induces sublethal damage; separation of human spermatozoa from seminal plasma by a dextran swim-up procedure without centrifugation extends their motilite lifetime Human Reproduction 8 1087-1092

Andersson L, Carrière F, Lowe ME, Nilson $\AA$ and Verger R (1996) Pancreatic lipase-related protein 2 but not classical pancreatic lipase hydrolyzes galactolipids Biochimica et Biophysica Acta 1302 236-240

Ashizawa K, Katayama S, Kobayashi T and Tsuzuki Y (1994) Possible role of protein kinase $C$ in regulation of flagellar motility and intracellular free $\mathrm{Ca}^{2+}$ concentration of fowl spermatozoa Journal of Reproduction and Fertility 101 511-517

Borgström B and Erlanson C (1973) Pancreatic lipase and co-lipase. Interactions and effects of bile salts and other detergents European Journal of Biochemistry $3760-68$

Breitbart H, Lax J, Rotem R and Naor Z (1992) Role of protein kinase C in the acrosome reaction of mammalian spermatozoa Biochemical Journal 281 473-476

Bucolo G and David H (1973) Quantitative determination of serum triglycerides by the use of enzymes Clinical Chemistry 19476

Carrière F, Thirstrup K, Boel E, Verger R and Thim L (1994) Structure-function relationships in naturally occurring mutants of pancreatic lipase Protein Engineering 7 563-569

Chaudhry PS and Casillas ER (1992) Isotypes of protein kinase C in bovine sperm Archives of Biochemistry and Biophysics 295 268-272

Chauhan Ms and Anand SR (1990) Effect of egg yolk lipids on the freezing of goat semen Theriogenology 34 1003-1013

Colas G (1984) Semen technology in the ram. In The Male in Farm Animal Production pp 219-236 Ed. Courot. M. Martinus Nijhoff, Amsterdam

Corteel JM (1974) Viabilité des spermatozoïdes de bouc conservés et congelés avec ou sans leur plasma séminal: effet du glucose Annales de Biologie Animale Biochimie et Biophysigue 14 741-745

Corteel JM (1975) Effet du 'lavage' sur la conservation des spermatozoides de bouc a basse tempéerature Annales de Biologie Animale Biochimie et Biophysique 15 525-528

Corteel JM (1980) Effets du plasma séminal sur la survie et la fertilité des spermatozoïdes conservés in vitro. Reproduction Nutrition Developpement 20 1111-1123

Corteel JM (1990) Maitrise de la reproduction chez les caprins à vocation laitière 5th International Meeting on Animal Reproduction, Zaragoza pp 193-274

Courtens JL, Nunes JF and Corteel JM (1984) Induction of the acrosome reaction in the spermatozoa of the goat by secretions of the male accessory glands and milk Gamete Research 9 287-320

Foresta C, Rossato M and Virgilio FD (1995) Differential modulation by protein kinase $\mathrm{C}$ of progesterone-activated responses in human sperm Biochemical and Biophysical Research Communications 206 408-413

Frye LD and Friou GJ (1975) Inhibition of mammalian cytotoxic cell by phosphatidylcholine and its analogue Nature 258 333-335

Graham JK (1994) Effect of seminal plasma on the motility of epididymal and ejaculated spermatozoa of the ram and bull during the cryopreservation process Theriogenology 41 1151-1162

Grusby MJ, Nabavi N, Wong H, Dick RF, Bluestone JA, Schotz MC and Glimcher LH (1990) Cloning of an interleukin-4 inducible gene from cytotoxic T lymphocytes and its identification as a lipase Cell 60 451-459

Hjorth A, Carrière F, Cudrey C, Wöldike H, Boel E, Lawson DM, Ferrato F, Cambillau C, Dodson GG, Thim L and Verger R (1993) A structural domain (the lid) found in pancreatic lipases is absent in the guinea pig (phospho) lipase Biochemistry 32 4702-4707

Holt WV and Dott HM (1980) Chemically induced fusion between ram spermatozoa and avian erythrocytes; an ultrastructural study Journal of Ultrastructural Research $71311-320$

Iritani $A$ and Nishikawa $Y$ (1972) Studies on the egg yolk coagulating enzyme (phosphlipase) in goat semen. IX. Enzyme concentration in the semen 
collected from the Cowper's gland removed goat Memoirs of the College of Agriculture Kyoto University 101 57-63

Jennens ML and Lowe ME (1995) Rat GP-3 is a pancreatic lipase with inetic properties that differ from colipase-dependent pancreatic lipase Journal of Lipid Research 36 2374-2382

Jensen RG, Ferris AM, Lammi-Keefe CJ and Henderson RA (1990) Lipids of bovine and human milks: a comparison Journal of Dairy Science 73 223-240

Khan WA, Blobe G, Halpern A, Taylor W, Wetsel WC, Burns D, Loomis C and Hannun YA (1993) Selective regulation of protein kinase $C$ isoenzymes by oleic acid in human platelets Journal of Biological Chemistry 268 5063-5068

Laemmli U (1970) Cleavage of structural proteins during the assembly of the head of bacteriophage T4 Nature 227 680-685

Lax X, Rubinstein S and Breitbart H (1994) Epidermal growth factor induces acrosomal exocytosis in bovine sperm FEBS letters $339234-238$

Leman J and Kinsella JE (1989) Surface activity, film formation and emulsifying properties of milk proteins Crifical Rewiews in Food Science and Nutrition $\mathbf{2 8}$ $115-138$

Lu G, Morinelli TA, Meier KE, Rosenzweig SA and Egan BM (1996) Oleic acid-induced mitogenic signalling in vascular smooth muscle cells. A role for protein kinase C Circulation Research $79611-618$

Meizel S (1984) The importance of hydrolitic enzymes to an exocytotic event, the mammalian sperm acrosome reaction Bioloical Reviews 59 125-157

Meizel S and Turner KO (1983) Stimulation of fan exocytotic event, the hamster sperm acrosome reaction, by cis-unsaturated fatty acids FEBS Letters $161315-318$

Memon MA, Bretzlaff KN and Ott RS (1985) Effect of washing on motility and acrosome morphology of frozen-thawed goat spermatozoa American Journal of Veterinary Research 46 473-475.

Momsen WE and Brockman HL (1976) Effects of colipase and taurodeoxycholate on the catalytic and physical properties of pancreatic lipase $B$ at an oil-water interface journal of Biological Chemistry 251 378-383

Nunes JF (1982) Etude des effets du plasma séminal sur la survie in vitro des spermatozoides de bouc Thèse doctorat Université Pierre et Marie Curie. Paris Vl

Nunes JF, Corteel JM, Combarnous Y and Baril G (1982) Rôle du plasma séminal dans la survie in vitro des spermatozoïdes de bouc Reproduction Nutrition Developement 22 611-620

Ordway RW, Singer JJ and Walsh JV (1991) Direct regulation of ion channels by fatty acids Trends in Neurosciences 14 96-100

Padilla AW and Foote RH (1991) Extender and centrifugation effects on the motility pattems of slow-cooled stallion spermatozoa Joumal of Animal Science 69 3308-3313

Pellicer-Rubio MT, Magallon T and Combarnous Y (1997) Deterioration of goat sperm viability is due to a bulbourethral $60 \mathrm{kD}$ glycoprotein with triglyceride lipase activity Biology of Reproduction 57 1023-1031
Pérez MD, Sánchez L, Aranda P, Ena JM, Oria R and Calvo M (1992) Effect of B-lactoglobulin on the activity of pregastric lipase. A possible role for this protein in ruminant milk Biochimica et Biophysica Acta 1123 151-155

Pickett BW, Sullivan JJ, Byers WW, Pace MM and Remmenga EE (1975) Effect of centrifugation and seminal plasma on motility and fertility of stallion and bull spermatozoa Fertility and Sterility 26 167-174

Pierre A, Fauquant J, Graet VL, Piot M and Maubois JL (1992) Préparation de phosphocaséinate natif par microfiltration sur membrane Lait 72 461-474

Rana APS, Majumder GC, Misra S and Ghosh A (1991) Lipid changes of goat sperm plasma membrane during epididymal maturation Biochimica et Biophysica Acta 1061 185-196

Roldán ERS and Fragio C (1993) Phospholipase A2 activation and subsequent exocytosis in the $\mathrm{Ca}^{2+} /$ ionophore-induced acrosome reaction of ram spermatozoa Journal of Biological Chemistry 26813 962-13 970

Rotem R, Paz GF, Homonnai ZT, Kalina M and Naor Z (1990) Protein kinase C is present in human sperm: possible role in flagellar motility Proceedings of the National Academy of Sciences USA 87 7305-7308

Rotem R, Paz GF, Homonnai ZT, Kalina M and Lax J (1992) $\mathrm{Ca}^{2+}$-independent induction of acrosome reaction by protein kinase $\mathrm{C}$ in human sperm Endocrinology $1312235-2243$

Roy A (1957) Egg-yolk coagulating enzyme in the semen and Cowper's glands of the goat Nature 179 318-319

Rubinstein S, Lax Y, Shalev Y and Breitbart H (1995) Dual effect of spermin on acrosomal exocytosis in capacitated bovine spermatozoa Biochimica ef Biophysica Acta 1266 196-200

Shinomura T, Asaoka Y, Oka M, Yoshida K and Nishizuka Y (1991) Synergistic action of diacylglycerol and unasturated fatty acid for protein kinase $C$ activation: its possible implications Proceedings of National Academy of Sciences USA 88 5149-5153

Sun QY, Liu H, Li XB, Song XF, Yu JQ, Li GH and Chen DY (1996) The role of $\mathrm{Ca}^{2+}$ and protein kinase $\mathrm{C}$ in the acrosome reaction of giant panda (Ailuropoda melanoleuca) spermatozoa Theriogenology 46 359-367

Thirstrup K, Verger R and Carrière F (1994) Evidence for a pancreatic lipase subfamily with new kinetic properties Biochemistry 33 2748-2756

Tiez NW and Fiereck EA (1966) A specific method for serum lipase determination Clinica et Chimica Acta 13352

Tollner TL, Overstreet JW and Vandevoort CA (1995) Effect of protein kinase C stimulators on zona pellucida binding and the acrosome reaction of macaque sperm Biology of Reproduction 52 1418-1425

Veisseyre $\mathbf{R}$ (1980) Caracteres, composición y estructura de la leche. In Lactologia Técnica pp 1-46 Acribia, Zaragoza

Verger R, Rietsch J and Desnuelle P (1977) Effects of colipase on hydrolysis of monomolecular films by lipase Journal of Biological Chemistry 252 $4319-4325$ 